\title{
Pendampingan Kader Puskesmas Dalam Pengelolaan Limbah Rumah Tangga Sebagai Kompos
}

\author{
Maksuk*1, Lukman² $^{2}$ \\ 1,2 Program Studi DIII Keperawatan, Politeknik Kesehatan Kemenkes Palembang \\ *e-mail : maksuk@poltekkespalembang.ac.id
}

\begin{abstract}
The cadres of public health center have an important role in managing of households in the community, therefore it is important to improve skills to manage such waste so that the waste can be utilized and beneficial. The method of managing household waste in this activity uses the concept of Pilah - Kumpul Manfaat - Untung (PKMU) to reduce the volume of household waste and provide benefits to the community. Participants involved in this activity were health workers, kader of community health centers and the community of RT 14 and RT 33. The Achievement targets in this activity were to improve the ability of health workers and cadres to manage of household waste, use of household waste for the planting of medicinal plants, families and the formation of independent care working groups for batra activities in health center and the formation of waste bank managers. The results of this activity show that cadres and the community can use household waste as compost, in addition, household waste such as plastic can be reused. The follow up of this activity is the formation of a waste bank manager at the location of the activity.
\end{abstract}

Keywords: Cadre, Management of Household Waste

\begin{abstract}
Abstrak
Kader puskesmas mempunyai peran penting dalam mengelola limbah rumah tangga di masyarakat, karena itu peningkatan keterampilan untuk mengelola limbah tersebut penting dilakukan agar limbah tersebut dapat dimanfaatkan dan menguntungkan. Metode pengelolaan limbah rumah tangga menggunakan konsep Pilah - Kumpul - Manfaat - Untung (PKMU) untuk mengurangi volume sampah rumah tangga dan menguntungkan masyarakat. Peserta yang terlibat dalam kegiatan ini terdiri dari petugas kesehatan, kader puskesmas dan masyarakat yang berasal dari di RT 14 dan RT 33. Target capaian dalam kegiatan ini adalah peningkatan kemampuan petugas kesehatan dan kader dalam mengelola limbah rumah tangga, pemanfaatan limbah rumah tangga untuk media penanaman tanaman obat, keluarga serta pembentukan kelompok kerja asuhan mandiri kegiatan batra di puskesmas dan pembentukan pengelola bank sampah. Hasil dari kegiatan ini menunjukkan bahwa kader dan masyarakat dapat memanfaatkan sampah rumah tangga sebagai membuat kompos. Selain itu limbah rumah tangga seperti plastik dapat dimanfaatkan kembali. Tindak lanjut dari kegiatan ini yaitu terbentuknya pengelola bank sampah di lokasi kegiatan.
\end{abstract}

Kata kunci: Kader, Pengelolaan Limbah Rumah Tangga

\section{PENDAHULUAN}

Sampah rumah tangga merupakan sisa-sisa dari kegiatan sehari-hari yang dihasilkan masyarakat termasuk didalamnya sisa-sisa bahan yang tidak dimanfaatkan atau dibuang. Kondisi ini lama kelamaan dapat meningkatkan jenis dan volume sampah sehingga dapat mencemari lingkungan dan menyebabkan berbagai masalah terutama masalah kesehatan bagi masyarakat. Permasalahan sampah sampai saat ini menjadi masalah yang belum dapat diatasi secara optimal dan masih perlu dilakukan pengelolaan terutama sampah yang dihasilkan dari rumah tangga.

Pengelolaan sampah yang belum optimal dilakukan oleh masyarakat dan pemerintah daerah dapat mempengaruhi lingkungan dan kesehatan masyarakat sekitarnya serta menyebabkan kerugian, diantaranya: menimbulkan bau busuk, mengganggu keindahan, menyebabkan banjir, meningkatnya pemanasan iklim, memperburuk sanitasi lingkungan dan ancaman meningkatnya berbagai macam penyakit (Yudistirani, 2015). 
Sampah yang tidak dikelola dengan baik berkontribusi terhadap keindahan lingkungan, pencemaran udara dan berdampak terhadap gangguan kesehatan masyarakat diantaranya penyakit pernafasan, diare, demam berdarah dan penyakit menular lainnya (World Bank, 2012). Oleh karena itu masyarakat sebagai sumber penghasilkan sampah pada level rumah tangga harus diberdayakan dan dilibatkan secara aktif dalam pengelolaan sampah.

Masalah sampah di Indonesia termasuk Kota Palembang merupakan masalah yang sulit diatasi karena kurangnya kesadaran, kepedulian dan partisipasi masyarakat untuk memelihara kebersihan serta memilah sampah sebelum dibuang. Peningkatan volume sampah di perkotaan termasuk Kota Palembang berbanding lurus dengan pertambahan jumlah penduduk. Jumlah penduduk Kota Palembang sampai saat ini sekitar 1.643.488 jiwa, dengan jumlah penduduk yang mencapai 1,6 juta jiwa tentunya akan menyumbangkan berbagai jenis sampah terutama yang berasal dari rumah tangga (BPS Kota Palembang, 2019).

Setiap harinya volume sampah yang dihasilkan di Kota Palembang kurang lebih 700 ton/hari dan setiap orang dapat menghasilkan sampah di kota besar termasuk Palembang sekitar 0,5 kg/orang/hari. (DKK Palembang, 2016). Pengelolaan sampah di Kota Palembang masih bertumpu pada pendekatan akhir (end of pipe) yaitu sampah dikumpulkan, diangkut dan dibuang ke tempat pembuangan akhir (TPA). Salah satu Tempat Pembuangan Akhir (TPA) sampah di Kota Palembang yaitu TPA Sukawinatan yang beroperasi sejak tahun 1994 dengan luas lahan 25 hektar telah terpakai 15 hektar, dan sisa lahan 10 hektar diperkirakan dapat menampung sampah hingga tahun 2017 (DKK Palembang, 2016).

Oleh karena itu pengelolaan sampah dapat lebih optimal jika ada kerjasama antara petugas kesehatan, kader puskesmas, masyarakat dan pemerintah setempat. Melalui keterlibatan masyarakat tersebut, maka mereka lebih mempercayai program pembangunan jika dilibatkan dalam suatu kegiatan dari mulai proses persiapan dan perencanaan serta sampai tahap pelaksanaan (Maulina, 2012).

Berdasarkan hasil survei pendahuluan yang dilakukan sebelum kegiatan pengabdian masyarakat ini dilakukan diperoleh gambaran bahwa sampah di wilayah kerja Puskesmas Satu Ulu tertumpuk dimana - mana dan pada saat musim hujan sampah terbawa aliran air ke sungai. Melalui pendekatan pengelolaan sampah rumah tangga berbasis masyarakat dengan melibatkan unsur pemerintah, petugas kesehatan, kader dan masyarakat diharapkan diperoleh solusi inovatif untuk membiasakan masyarakat dalam mengelola sampah sejak dari level rumah tangga.

Oleh karena itu perlu dilakukan pengelolaan sampah secara terintegrasi berbasis masyarakat dengan berkolaborasi dengan pemerintah, petugas kesehatan dan kader sebagai fasilitator di wilayah kerjanya. Pendekatan pengelolaan sampah yang didasarkan pada kebutuhan masyarakat, direncanakan, dilaksanakan, dikendalikan dan dievaluasi bersama masyarakat dapat mengurangi volume sampah yang berasal dari rumah tangga (Sidik, 2009). Sistem penanganan sampah yang direncanakan, disusun, dioperasikan, dikelola dan dimiliki oleh masyarakat (Yuwono dkk, 2008).

\section{METODE}

Permasalahan pada kelompok sasaran (mitra) yaitu masalah sampah rumah tangga yang semakin meningkat dan belum diolah secara optimal. Selain itu kurangnya informasi dan kesadaran masyarakat untuk memanfaatkan kembali sisa - sisa sampah rumah tangga yang mereka hasilkan. Kegiatan ini difokuskan pada kegiatan pengelolaan limbah rumah tangga yang dilaksanakan bersama - sama kader dan petugas puskesmas dengan cara memanfaatkan sisa sisa sayuran dan sampah organik lainnya sebagai kompos untuk digunakan sebagi media tanaman obat keluarga.

Kegiatan pengabdian kepada masyarakat dilaksanakan di RT 14 dan RT 33 Kelurahan Satu Ulu pada tanggal 12-13 Juli 2019. Sasaran kegiatan PKM adalah 20 kader, 5 petugas kesehatan. Kegiatan PKM ini dilaksanakan oleh 2 dosen dan dibantu oleh 5 mahasiswa DIII Keperawatan. 
Pada kegiatan ini mahasiswa bertugas membantu menyiapkan alat dan bahan yang digunakan untuk pembuatan kompos, pengisian daftar hadir dan pemberian konsumsi kepada peserta PKM. Kegiatan ini dilakukan dengan cara demonstrasi cara pembuatan kompos sederhana kepada peserta PKM.

Tahapan pelaksanaan kegiatan difokuskan pada 3 kegiatan yaitu:

1. Sosialisasi pemilahan limbah rumah tangga dan memanfaatkan kembali sampah

2. Simulasi pembuatan kompos dari sisa - sisa sayur atau sampah organik lainnya untuk penanaman tanaman obat keluarga.

\section{HASIL DAN PEMBAHASAN}

Program ini merupakan pengabdian kepada masyarakat yang lebih fokus pada kegiatan pemberdayaan masyarakat dalam pengelolaan limbah rumah tangga yaitu peningkatan keterampilan petugas dan kader puskesmas dalam melakukan pengelolaan limbah rumah tangga. Sesuai dengan tahapan pelaksanaan, maka kegiatan ini dimulai dengan sosialisasi tentang pemilahan limbah rumah tangga dan memanfaatkan kembali limbah terebut sebagai kompos. Ini dilaksanakan pada tanggal 12 Juli 2019 bertempat di Lapangan RT 14. Peserta yang hadir dari kader, masyarakat dan petugas kesehatan Puskesmas Satu Ulu.

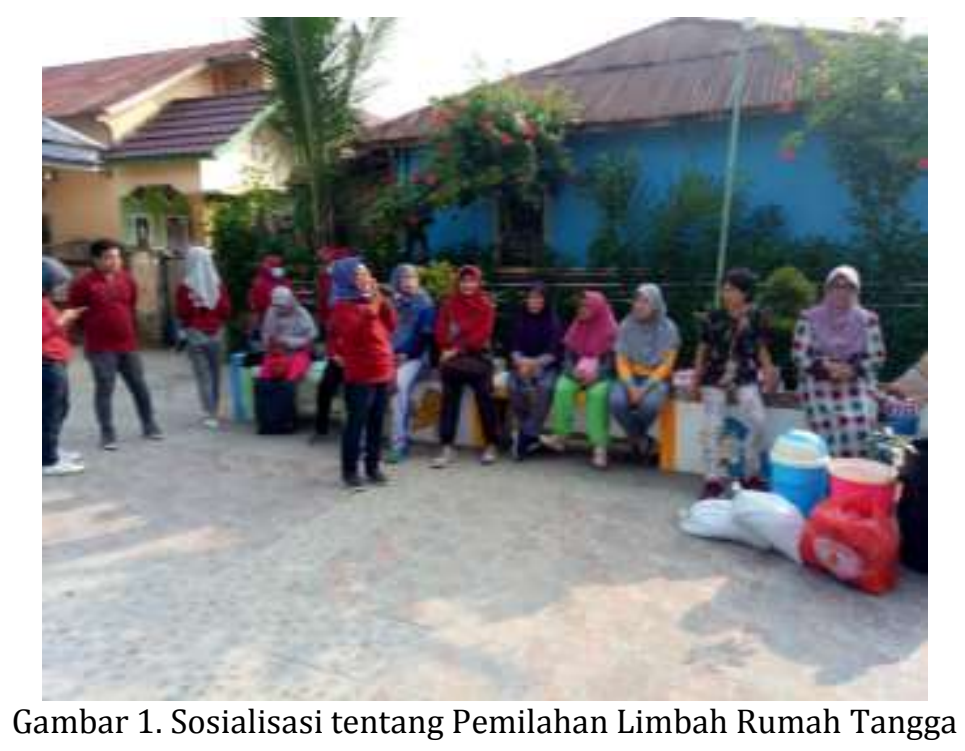

Selanjutnya adalah melaksanakan kegiatan pembuatan kompos dari sisa - sisa sayur atau sampah organik lainnya. Setelah itu menanam tanaman obat keluarga sebagai salah implementasi kegiatan batra di puskesmas.

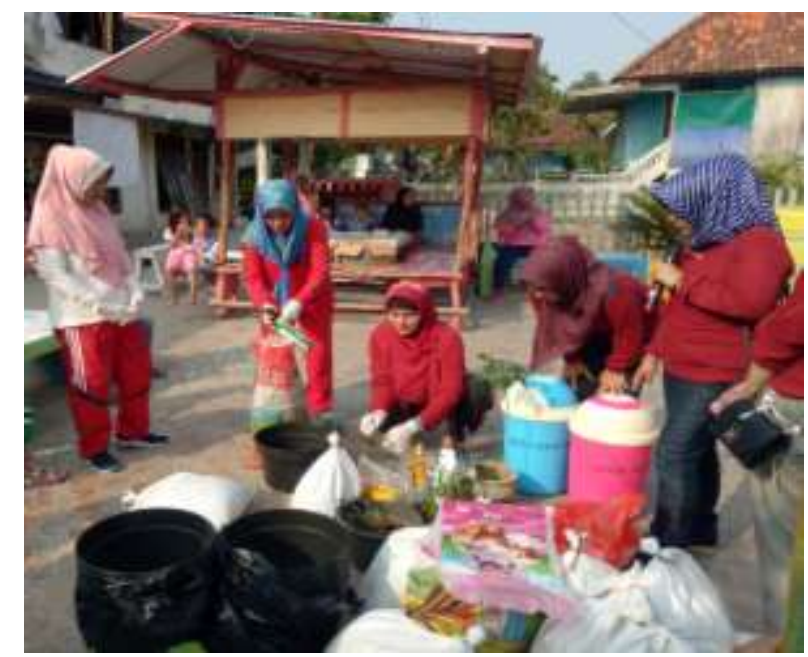

Gambar 2. Demonstrasi Pembuatan Kompos 
Kegiatan ini juga diselingi dengan diskusi tentang pemanfaatan limbah rumah tangga terutama sisa - sisa plastik bekas minyak, sabun cair dan lain-lain untuk menanam tanaman obat keluarga, masyarakat sangat antusias mengikuti kegiatan ini.

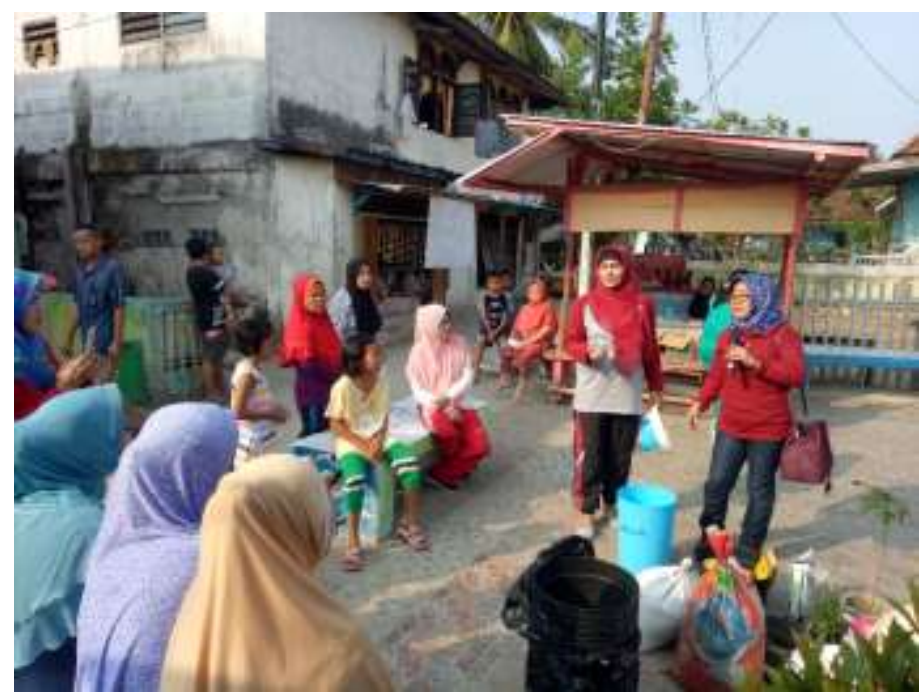

Gambar 3. Diskusi masalah pemanfaatan limbah plastik

Setelah selesai diskusi mengenai pengelolaan limbah rumah tangga kepada kader dan masyarakat, maka selanjutnya tim melakukan pendampingan kepada petugas dan kader dalam membuat kompos sederhana dan menanam tanaman obat keluarga.

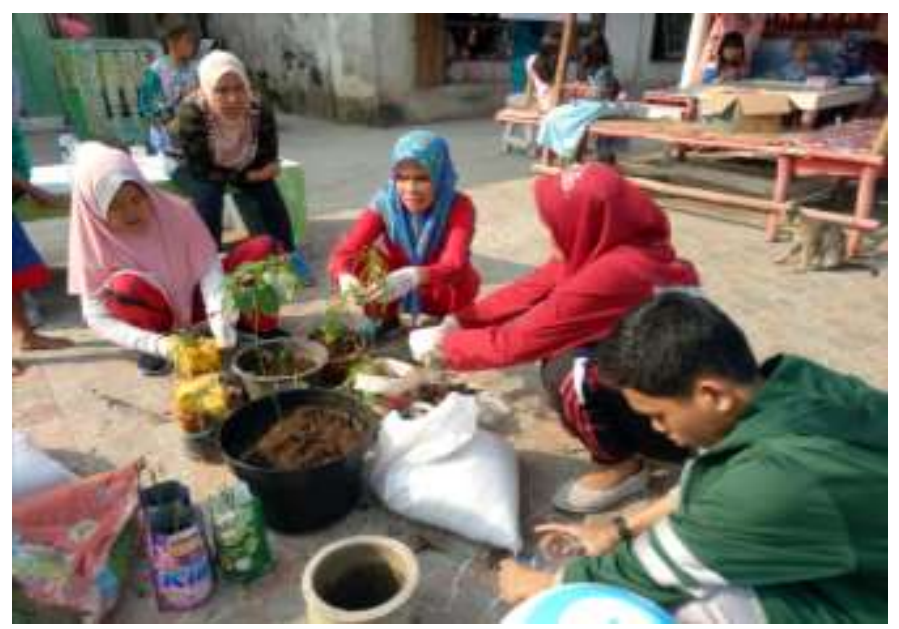

Gambar 5. Mendampingi kader menanam tanaman obat menggunakan kompos

Untuk mengetahui lebih detail dan komprehensif terkait dengan pengetahuan mitra mengenai pengelolaan limbah rumah tangga, maka diakhir sesi, kami melakukan evaluasi dengan mengajukan beberapa pertanyaan kepada kader dan masyarakat. Dari beberapa pertanyaan yang diajukan dapat dijawab oleh kader dan masyarakat dengan baik dan selanjutnya mereka akan menerapkan pengelolaan limbah rumah tangga yang telah mereka gunakan.

Sesuai dengan amanat Undang-Undang Nomor 18 Tahun 2008 tentang Pengelolaan Sampah dan Peraturan Pemerintah Nomor 81 Tahun 2012 perlu perubahan paradigma yang mendasar dalam pengelolaan sampah yaitu dari paradigma kumpul- angkut-buang, menjadi pengolahan yang bertumpu pada pengurangan sampah dan penanganan sampah. Paradigma pengelolaan sampah yang bertumpu pada pendekatan akhir seharusnya sudah saatnya ditinggalkan dan diganti dengan paradigma baru dengan cara memanfaatkan sampah sehingga 
mempunyai nilai ekonomis dan dapat dimanfaatkan, diantaranya untuk kompos dan pupuk terutama pada tatanan rumah tangga.

Proses pemanfaatan sisa - sisa sayuran atau bahan organik lainnya sebagai bahan baku pembuatan kompos dapat mengurangi pencemaran lingkungan (Murbanono, 2002). Produk hasil pengomposan bermanfaat bagi tanah dan tanaman, dan dapat dimanfaatkan untuk pupuk tanaman obat keluarga atau tanaman lainnya. Oleh karena itu berdasarkan hal tersebut dalam kegiatan ini telah dilakukan simulasi pembuatan kompos sederhana yang selanjutnya dapat dilakukan sendiri oleh masyarakat di lingkungan RT 14 dan RT 33 wilayah kerja Puskesmas Satu Ulu Kota Palembang

Hambatan yang ditemukan selama melaksanakan kegiatan pengelolaan sampah berbasis masyarakat yaitu tingkat kesadaran warga yang masih rendah terutama dalam pemanfaatan sampah rumah tangga, karena sebelumnya masyarakat belum mendapatkan informasi mengenai pemanfaatan sampah rumah tangga, belum adanya kerjsama secara terintegrasi yang melibatkan masyarakat dalam pengelolaan sampah rumah tangga, selama ini masyarakat hanya terbiasa menerima bantuan peralatan untuk pengelolaan sampah rumah tangga tetapi masyarakat belum diberdayakan untuk melakukan pengelolaan sampah.

Beberapa hal yang menjadi kendala dalam pengelolaan sampah di wilayah kerja Puskesmas Satu Ulu Kota Palembang yaitu potensi masyarakat secara umum cukup besar, tetapi belum dapat dimanfaatkan secara optimal sebagai potensi untuk meningkatkan efektifitas program persampahan, adanya anggapan di masyarakat bahwa pengelolaan persampahan merupakan tanggung jawab pemerintah daerah. Selain itu masih kurangnya kesadaran masyarakat dalam memelihara kebersihan lingkungan khususnya dalam hal kebiasaan membuang sampah pada tempatnya dan kurang pengetahuan masyarakat dalam pemanfaatan kembali sampah.

Namun demikian, agar sampah dapat memberikan nilai ekonomis dan keuntungan bagi masyarakat maka melalui kegiatan pengabdian masyarakat ini dilakukan pembentukan pengelola bank sampah di wilayah kerja Puskesmas Satu Ulu Kota Palembang yang secara jangka panjang akan dikelola oleh masyarakat sendiri. Bank Sampah adalah tempat menabung sampah yang telah terpilah menurut jenis sampah (Aryeti, 2011). Bank Sampah dalam pelaksanaanya dapat mengurangi volume sampah di masyarakat dan di tempat pembuangan akhir (TPA). Pengelolaan sampah tidak hanya Bank Sampah, tetapi juga bisa melalui Sodaqoh Sampah dengan harapan agar semangat solidaritas, kebersamaan, handarbeni (rasa saling memiliki) tetap kuat dan berakar di dalam masyarakat (Perdana dkk, 2016).

Pengelolaan Bank Sampah juga mengikuti kaidah-kaidah yang terdapat dalam Undangundang Nomor 18 Tahun 2008 tentang Pengelolaan Sampah dengan prinsip 3R. Oleh karena itu sebagai target capaian jangka panjang dalam kegiatan pengabdian kepada masyarakat ini adalah terbentuknya pengelolaan sampah melalui Bank Sampah di wilayah kerja Puskesmas Satu Ulu Kota Palembang. Dalam pengelolaan sampah rumah tangga peran serta masyarakat sangat besar pengaruhnya untuk keberhasilan program pengelolaan sampah berbasis masyarakat (Artiningsi, 2008;Sidiq, 2009).

Oleh karena itu solusi pemecahan yang ditawarkan penulis dalam mengatasi persampahan yang ada tepatnya di wilayah kerja Puskesmas Satu Ulu Kota Palembang menggunakan metode pendekatan dengan paradigma Pilah-Kumpul-Manfaat-Untung (PKMU). Melalui metode ini sampah sudah mulai dilakukan pemilahan pada level rumah tangga sehingga cara ini membantu mengurangi volume sampah terutama plastik yang tidak mudah terurai di lingkungan.

\section{KESIMPULAN}

Adapun kesimpulan dari kegiatan pengabdian kepada msyarakat ini sebagai berikut: 
1. Kegiatan pertama PKM adalah sosialisasi pengelolaan limbah rumah tangga kepada kader puskesmas dan pemanfaatan kompos untuk menanam tanaman obat.

2. Kegiatan kedua demonstrasi pembuatan kompos dapat diikuti dengan baik oleh kader dan masyarakat.

3. Untuk kegiatan selanjutnya adalah membentuk pengelola bank sampah agar limbah rumah tangga memiliki nilai ekonomis dan menguntungkan masyarakat.

Rekomendasi dari hasil kegiatan pengabmas ini adalah:

1. Perlu adanya kerjasama yang baik antara dosen, aparat pemerintah dan masyarakat setempat agar kegiatan pengelolaan sampah rumah tangga dapat berjalan dengan baik dan berelanjuta.

2. Dalam rangka pengembangan bank sampah ke depan pemerintah perlu memfasilitasi dalam bentuk sosialisasi, pemberian dana hibah atau pinjaman modal, dan pelibatan pihak swasta, melalui Corporate Social Responsibility (CSR), untuk membantu pengembangan Bank Sampah.

\section{UCAPAN TERIMA KASIH}

Penulis mengucapkan terima kasih kepada Poltekkes Kemenkes Palembang yang telah memberi dukungan financial terhadap pengabdian ini. Tak lupa kami mengucapkan terima kasih kepada Kepala Puskesmas Satu Ulu dan staf yang telah memfasilitasi kegiatan ini sehingga dapat berjalan dengan baik dan lancar.

\section{DAFTAR PUSTAKA}

Artiningsih Ni Komang Ayu (2008). Peran Serta Masyarakat dalam Pengelolaan Sampah Rumah Tangga (Studi kasus di Sampangan dan Jomblang, Kota Semarang). Semarang: Tesis, UNDIP. Aryeti. (2011). Peningkatan Peran serta Masyarakat Melalui Gerakan Menabung pada Bank Sampah di Kelurahan Babakan Surabaya, Kiaracondong Bandung. Jurnal Permukiman. 6 (1), 40-46.

Badan Pusat Statistik Kota Palembang, (2019). Jumlah Penduduk Kota Palembang Tahun 2009

- 2018. https://palembangkota.bps.go.id/dynamictable/2019/12/09/104/jumlahpenduduk-kota-palembang-tahun-2009-2018.html

Dinas Kebersihan Kota Palembang, (2016). Profil Dinas Kebersihan Kota Palembang.

Maulina, AS, (2012). Identifikasi Partisipasi Masyarakat Dalam Pemilahan Sampah di Kecamatan Cimahi Utara Serta Faktor Yang Mempengaruhinya. Jurnal Perencanaan Wilayah dan Kota. 23 (3), 177 - 196.

Murbanono, HSL. (2002). Membuat Kompos. Penerbit Penebar Swadaya. Jakarta.

Perdana, HD, Hananto, TS, Bandi, Murni S, (2016). Peningkatan Sarana Prasarana Pengelolaan Sampah Rumah Tangga Desa Doplang Kabupaten Boyolali, JPKM, 22(4), 1-9.

Sidik, US. (2009). Implementasi Peran Masyarakat Sesuai UU NO. 18 Tahun 2008. Majalah Percik Bulan Mei, Edisi Khusus Pengelolaan Sampah Berbasis Masyarakat, Pokja AMPL, Jakarta.

Undang-Undang No. 18 Tahun 2008 tentang Pengelolaan Sampah.

Yudistirani, SA, Syaufina, L., Mulatsih, S. (2015). Desain Sistem Pengelolaan Sampah Melalui Pemilahan Sampah Organik dan Anorganik Berdasarkan Persepsi Ibu-ibu Rumah Tangga. Konversi. 4 (2), 29-42.

Yuwono, RL. Wardhani, U, Ninghadiyati, Adinugroho, E. (2008). Pengembangan Sistem Persampahan Berbasis Masyarakat. Pokja AMPL, Jakarta. 